\title{
The effect of angiotensin II on blood pressure in patients with circulatory shock: a structured review of the literature
}

\author{
Laurence W. Busse ${ }^{1 *}$, Michael T. McCurdy ${ }^{2,3}$, Osman Ali ${ }^{2}$, Anna Hall ${ }^{4}$, Huaizhen Chen ${ }^{1}$ and Marlies Ostermann ${ }^{4}$
}

\begin{abstract}
Background: Circulatory shock is a common syndrome with a high mortality and limited therapeutic options. Despite its discovery and use in clinical and experimental settings more than a half-century ago, angiotensin II (Ang II) has only been recently evaluated as a vasopressor in distributive shock. We examined existing literature for associations between Ang II and the resolution of circulatory shock.

Methods: We searched PubMed, MEDLINE, Ovid, and Embase to identify all English literature accounts of intravenous Ang II in humans for the treatment of shock (systolic blood pressure [SBP] $\leq 90 \mathrm{mmHg}$ or a mean arterial pressure $[\mathrm{MAP}] \leq 65 \mathrm{mmHg}$ ), and hand-searched the references of extracted papers for further studies meeting inclusion criteria. Of 3743 articles identified, 24 studies including 353 patients met inclusion criteria. Complete data existed for 276 patients. Extracted data included study type, publication year, demographics, type of shock, dosing of Ang II or other vasoactive medications, and changes in BP, lactate, and urine output. BP effects were grouped according to type of shock, with additional analyses completed for patients with absent blood pressure. Shock was distributive $(n=225)$, cardiogenic $(n=38)$, or from other causes $(n=90)$. Blood pressure as absent in 18 patients.
\end{abstract}

Results: For the 276 patients with complete data, MAP rose by $23.4 \%$ from $63.3 \mathrm{mmHg}$ to $78.1 \mathrm{mmHg}$ in response to Ang II (dose range: $15 \mathrm{ng} / \mathrm{kg} / \mathrm{min}$ to $60 \mathrm{mcg} / \mathrm{min}$ ). SBP rose by $125.2 \%$ from $56.9 \mathrm{mmHg}$ to $128.2 \mathrm{mmHg}$ (dose range: $0.2 \mathrm{mcg} / \mathrm{min}$ to a $1500 \mathrm{mcg}$ bolus). A total of 271 patients with complete data were determined to exhibit a BP effect which was directly associated with Ang II. Subgroups (patients with cardiogenic, septic, and other types of shock) exhibited similar increases in BP. In patients with absent BP, deemed to be cardiac arrest, return of spontaneous circulation (ROSC) was achieved, and BP increased by an average of $107.3 \mathrm{mmHg}$ in 11 of 18 patients. The remaining seven patients with cardiac arrest did not respond.

Conclusions: Intravenous Ang II is associated with increased BP in patients with cardiogenic, distributive, and unclassified shock. A role may exist for Ang II in restoring circulation in cardiac arrest.

Keywords: Angiotensin II, Distributive shock, Vasopressor, Vasoconstrictor, Cardiac arrest, Cardiogenic shock

\footnotetext{
* Correspondence: laurence.w.busse@emory.edu

${ }^{1}$ Department of Medicine, Division of Pulmonary, Critical Care, Allergy, and

Sleep Medicine, Emory University, Emory St. Joseph's Hospital, 5665

Peachtree Dunwoody Road, Atlanta, GA 30342, USA

Full list of author information is available at the end of the article
}

\section{Ciomed Central}

(c) The Author(s). 2017 Open Access This article is distributed under the terms of the Creative Commons Attribution 4.0 International License (http://creativecommons.org/licenses/by/4.0/), which permits unrestricted use, distribution, and reproduction in any medium, provided you give appropriate credit to the original author(s) and the source, provide a link to the Creative Commons license, and indicate if changes were made. The Creative Commons Public Domain Dedication waiver (http://creativecommons.org/publicdomain/zero/1.0/) applies to the data made available in this article, unless otherwise stated. 


\section{Background}

Circulatory shock is a life-threatening condition with a high risk of multi-organ failure and death and a paucity of treatment options [1]. Catecholamines and vasopressin are often required to achieve an adequate blood pressure (BP), sometimes at the risk of adverse events, including peripheral and splanchnic ischemia, dysrhythmias, and organ dysfunction [2-5]. To date, no specific vasopressor has been shown to improve outcomes [6-8]. A 2015 meta-analysis by Zhou et al. concluded that other than the superiority of norepinephrine over dobutamine, no vasopressor outperformed any other with respect to mortality [9]. Two recent randomized controlled trials have renewed interest in angiotensin II (Ang II) for circulatory shock [10, 11]. In both of these studies, Ang II was hypothesized to increase mean arterial pressure (MAP) in patients with circulatory shock, as an adjunctive therapy to catecholamines and vasopressin standard-of-care therapy.

Ang II is a naturally occurring octapeptide that increases BP through various mechanisms, including vasoconstriction of peripheral vessels, potentiation of antidiuretic hormone $(\mathrm{ADH})$ and adrenocorticotropin hormone $(\mathrm{ACTH})$ release, and direct actions on postganglionic sympathetic fibers [12]. Following its discovery in the 1930s, Ang II has been administered to humans clinically and experimentally [13-18]. Considerable literature surrounds the clinical and experimental use of Ang II [19]. However, to our knowledge, no systematic evaluation has associated Ang II administration with improved BP in hypotensive states.

\section{Methods}

\section{Study selection}

We performed a review of all published reports of intravenous Ang II use in humans. We included full manuscripts published in English, excluding commentaries, conference presentations, duplicate reports, and animal studies.

The literature search was performed independently by two separate groups (MM and OA, MO and $\mathrm{AH}$ ). Databases searched included PubMed, MEDLINE, Ovid, and Embase using the following search terms: "angiotensin" AND ("hypotension" or "shock") AND "intravenous" AND "human," and repeated using "hypertensin" or "angiotonin" as alternatives to "angiotensin." Subsequently, we handsearched the references of extracted papers for additional studies meeting inclusion criteria.

Abstracts were reviewed by the same two groups of authors, who independently selected eligible studies. Circulatory shock was defined as MAP $<65 \mathrm{mmHg}$ or systolic blood pressure (SBP) $<90 \mathrm{mmHg}$. For inclusion in the analysis, study subjects with circulatory shock were required to have received Ang II (+/- concomitant medications) and have post-Ang II BP documented. Disagreements on study selection were adjudicated by a fifth author (LB) not involved in the original literature search.
The following data were extracted: study type, publication year, patient demographics, dose and duration of Ang II administration, dose and duration of other concomitant vasoactive medications, type of shock, and effects on BP, lactate and urine output (UOP). For studies reporting the use of Ang II in patients with and without hypotension, only patients with hypotension were analyzed. In studies reporting the effects of multiple vasoactive agents, only those patients receiving Ang II $(+/$ - additional agents) were included. Figure 1 illustrates the literature selection process.

\section{Data analysis}

Studies were analyzed for quantitative effects of Ang II on BP. The primary outcome was the change in MAP or SBP in association with Ang II. Individual patient data were extracted where available, allowing for standard error (SE) calculation. SE calculations did not include compiled data (i.e., 163 patients from the Angiotensin II for the Treatment of High Output Shock (ATHOS)-3 study for which no individual patient data were available). Results of each study were compiled and weighted according to the number of patients included in each study. Patients with missing or qualitative data were excluded from all calculations and described elsewhere. As a sub-analysis, we explored the association of Ang II in different types of shock, including cardiogenic, distributive, and other etiologies. Additionally, we performed an analysis of patients in whom BP was reported as zero or absent, which we defined as a condition of cardiac arrest. We performed sensitivity analyses by grading each study according to study type, and performed the original analysis for each category. Randomized, controlled trials (RCT) were graded as "A," case controls as "B," and case reports as "C." Finally, we calculated changes in BP for the total population as well as for the septic shock cohort excluding ATHOS-3 patients, which represented nearly half of the total patient population.

\section{Results}

The search in Ovid, MEDLINE, Embase, and PubMed retrieved 3743 potentially relevant abstracts, of which 95 articles were eligible for a more detailed evaluation. After full text evaluation, another 71 were excluded. Of the remaining 24 studies, two were RCTs, nine were case-control studies, and 13 were case reports. Details are shown in Fig. 1.

\section{Effects on blood pressure}

In total, 353 patients with hypotension were administered Ang II, including 276 with complete data. Individual results of the selected studies, including dose ranges, median dose and interquartile dose ranges, are displayed in Table 1. Patients were hypotensive due to various etiologies, including cardiogenic $(n=38)$, distributive or 


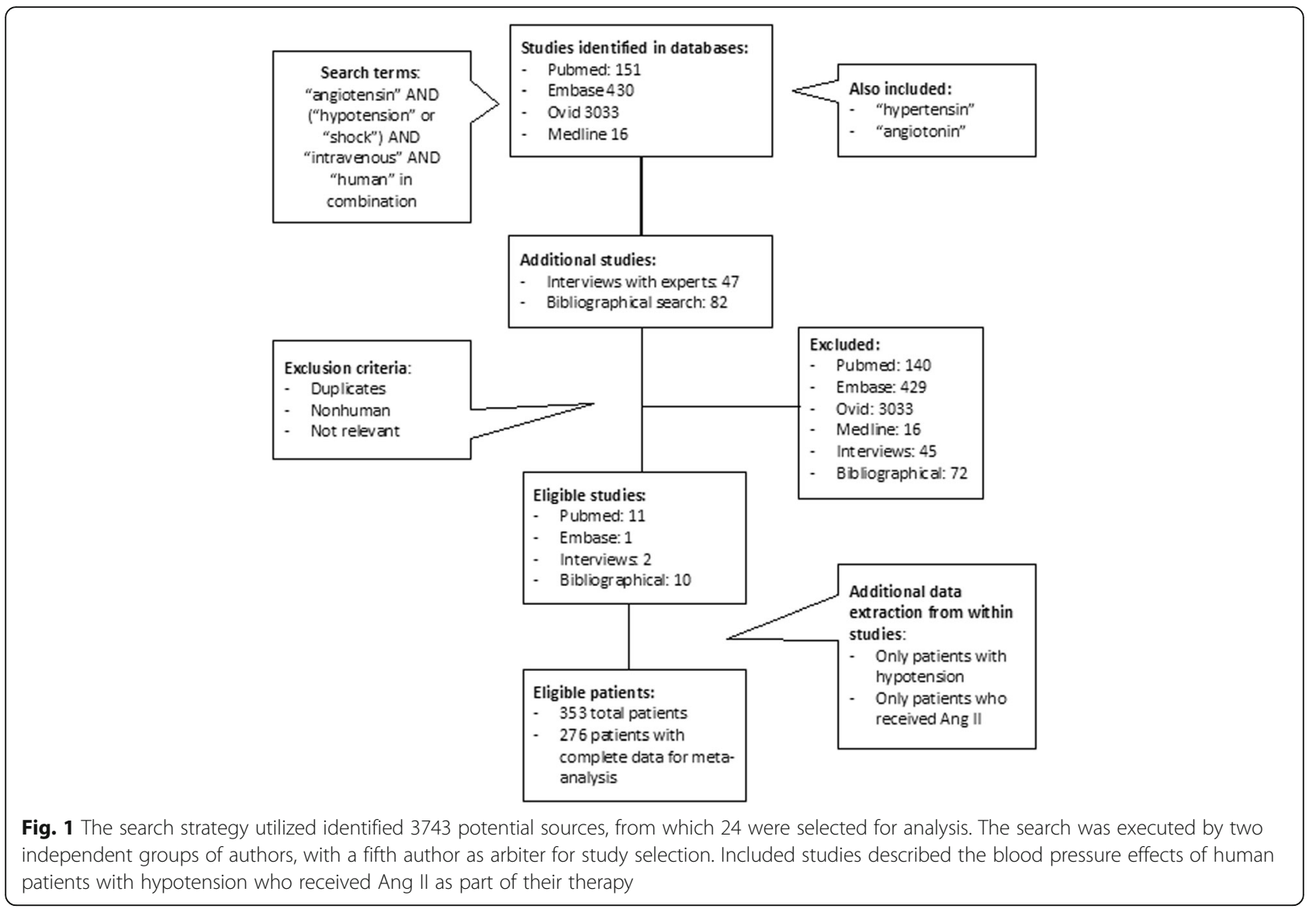

septic $(n=225)$, or other causes $(n=90)$. For the purposes of this analysis, some forms of vasodilatory shock, such as neurogenic and medication-induced shock, were included as other causes of shock. In studies reporting changes in MAP $(n=218)$, BP rose by $23.4 \%$, from an initial (i.e., prior to Ang II administration) weighted mean of $63.3 \mathrm{mmHg}$ to $78.1 \mathrm{mmHg}$ at an Ang II dose of $15 \mathrm{ng} / \mathrm{kg} / \mathrm{min}$ to $60 \mathrm{mcg} / \mathrm{min}$; SE of the mean $(n=45)$ was $+/-14.0 \mathrm{mmHg}$. In studies reporting changes in SBP $(n=58)$, BP rose by $125.2 \%$ from $56.9 \mathrm{mmHg}$ to $128.2 \mathrm{mmHg}$ at a dose of $0.2 \mathrm{mcg} / \mathrm{min}$ to a $1500 \mathrm{mcg}$ bolus; SE of the mean $(n=44)$ was $+/-53.2 \mathrm{mmHg}$. One study $(n=8)$ reported an increase of diastolic blood pressure (DBP) by $20 \mathrm{mmHg}$ from an initial average BP of $76 / 48 \mathrm{mmHg}$, at a dose range of 490 to $840 \mathrm{ng} / \mathrm{min}$.

We performed a further analysis on all included patients to discern whether any of the observed BP effect could be associated with medications other than Ang II. As shown in Table 2, of all 353 patients described, 330 (93.4\%) were thought to have realized a BP effect directly attributable to Ang II. Of these, 148 patients (41.9\% of the total) received only Ang II. Of the 276 patients with complete data, 271 (98.1\%) had BP effects attributed directly to Ang II. Nine patients were deemed to have realized a BP effect that could not be attributed to Ang II alone. These nine patients received various other pressors at varying doses (Table 2).

\section{Effects on BP by type of shock}

Patients were further classified into subgroups based on the type of shock (Tables 3, 4, and 5). Of 38 patients with cardiogenic shock, 13 had complete data. SBP ( $n=$ 10) rose by $53.9 \mathrm{mmHg}$ at an Ang II dose range of 1.2 $\mathrm{mcg} / \mathrm{min}$ to a $350 \mathrm{mcg}$ bolus, and MAP $(n=3)$ rose by $40.0 \mathrm{mmHg}$ at a dose range of $6 \mathrm{mcg} / \mathrm{min}$ for one patient, with data unavailable for the other two. Of 225 patients with distributive or septic shock, 198 had complete data. SBP $(n=14)$ rose by $53.9 \mathrm{mmHg}$ at a dose range of $0.2 \mathrm{mcg} / \mathrm{min}$ to a bolus of $120 \mathrm{mcg}$, and MAP $(n=184)$ rose by $13.3 \mathrm{mmHg}$ at a dose range of $15 \mathrm{ng} / \mathrm{kg} / \mathrm{min}$ to $4.2 \mathrm{mcg} / \mathrm{min}$ (with dose ranges available for only 174 patients). Of 90 patients with shock due to other etiologies (e.g., hemorrhagic shock, neurogenic shock, shock associated with chronic dialysis), 83 had complete data. SBP $(n=35)$ rose by $80.0 \mathrm{mmHg}$ at a dose range of $0.8 \mathrm{mcg} / \mathrm{min}$ to a $1500 \mathrm{mcg}$ bolus. MAP $(n=48)$ increased by $12.0 \mathrm{mmHg}$ at a dose of 0.3 to 60 $\mathrm{mcg} / \mathrm{min}$. 
Table 1 Blood pressure effect of angiotensin II from entire cohort

\begin{tabular}{|c|c|c|c|c|c|c|c|}
\hline \multirow[t]{2}{*}{ Author (year) } & \multirow[t]{2}{*}{ Cases Total/+data } & \multicolumn{3}{|c|}{ Type of shock } & \multirow[t]{2}{*}{$\mathrm{SBP} \uparrow(\mathrm{mmHg})$} & \multirow[t]{2}{*}{$\mathrm{MAP} \uparrow(\mathrm{mmHg})$} & \multirow{2}{*}{$\begin{array}{l}\text { Dose range } \\
\text { Median } \\
\text { (IQR) }\end{array}$} \\
\hline & & Septic & Other & Cardiogenic & & & \\
\hline Del Greco (1961) [25] & $20 / 20$ & 7 & 11 & 2 & 47.4 & & $\begin{array}{l}0.23-100 \mathrm{mcg} / \mathrm{min} \\
2.5 \mathrm{mcg} / \mathrm{min} \\
(13.5)\end{array}$ \\
\hline Nassif (1963) [34] & $14 / 13$ & 6 & 6 & 2 & 106.9 & & $\begin{array}{l}7-1500 \mathrm{mcg} \text { bolus } \\
14 \mathrm{mcg} / \mathrm{min} \\
(32)\end{array}$ \\
\hline Wedeen (1963) [35] & $15 / 7$ & 1 & 3 & 11 & 81.1 & & $\begin{array}{l}1.5-36 \mathrm{mcg} / \mathrm{min} \\
10 \mathrm{mcg} / \mathrm{min} \\
(6.5)\end{array}$ \\
\hline Beanlands (1964) [36] & $17 / 0$ & 0 & 0 & 17 & a & & $\begin{array}{l}1-36 \mathrm{mcg} / \mathrm{min} \\
2 \mathrm{mcg} / \mathrm{min} \\
(2.25)\end{array}$ \\
\hline Udhoji (1964) [26] & $12 / 6$ & 4 & 5 & 3 & & 34.3 & b \\
\hline Belle (1965) [37] & $1 / 1$ & 0 & 0 & 1 & 16.0 & & $\begin{array}{l}\text { 50-250 mg/day } \\
- \\
-\end{array}$ \\
\hline Cohn (1965) [27] & $6 / 6$ & 6 & 0 & 0 & & 29.7 & b \\
\hline Cohn (1965) [27] & $22 / 22$ & 0 & 22 & 0 & & 22.1 & $\begin{array}{l}0.3-60 \mathrm{mcg} / \mathrm{min} \\
14.1 \mathrm{mcg} / \mathrm{min} \\
-\end{array}$ \\
\hline Singh (1966) [28] & $25 / 0$ & 25 & 0 & 0 & c & & $\begin{array}{l}4-12 \mathrm{mcg} / \mathrm{min} \\
- \\
-\end{array}$ \\
\hline Wallace (1967) [29] & $7 / 7$ & 0 & 7 & 0 & & 22.9 & $\begin{array}{l}0.75-\mathrm{mcg} / \mathrm{min} \\
1.5 \mathrm{mcg} / \mathrm{min} \\
(0)\end{array}$ \\
\hline Sorensen (1986) [32] & $8 / 0$ & 0 & 8 & 0 & $d$ & & b \\
\hline Moore (1989) [33] & $9 / 0$ & 0 & 9 & 0 & e & & $\begin{array}{l}2.9 \mathrm{ng} / \mathrm{kg} / \mathrm{min} \\
-\end{array}$ \\
\hline Geary (1990) [38] & $1 / 1$ & 0 & 0 & 1 & & 30.0 & $\begin{array}{l}6 \mathrm{mcg} / \mathrm{min} \\
- \\
-\end{array}$ \\
\hline Thacker (1990) & $2 / 2$ & 0 & 2 & 0 & & 27.5 & $\begin{array}{l}6-7 \mathrm{mcg} / \mathrm{min} \\
6.5 \mathrm{mcg} / \mathrm{min} \\
-\end{array}$ \\
\hline Thomas (1991) [40] & $1 / 0$ & 1 & 0 & 0 & & $f$ & $\begin{array}{l}5-20 \mathrm{mcg} / \mathrm{min} \\
10 \mathrm{mcg} / \mathrm{min} \\
-\end{array}$ \\
\hline Jackson (1993) [20] & $1 / 0$ & 0 & 1 & 0 & g & & $\begin{array}{l}3-18 \mathrm{mcg} / \mathrm{min} \\
18 \mathrm{mcg} / \mathrm{min} \\
-\end{array}$ \\
\hline Trilli (1994) [21] & $1 / 1$ & 0 & 0 & 1 & 24.0 & & $\begin{array}{l}8.5-9 \mathrm{mcg} / \mathrm{min} \\
8.5 \mathrm{mcg} / \mathrm{min} \\
-\end{array}$ \\
\hline Ryding (1995) [41] & $1 / 1$ & 1 & 0 & 0 & & 18.0 & $\begin{array}{l}3.5-4.2 \mathrm{mcg} / \mathrm{min} \\
- \\
-\end{array}$ \\
\hline Newby (1995) [22] & $1 / 1$ & 0 & 1 & 0 & 30.0 & & $\begin{array}{l}0.8-2.2 \mathrm{mcg} / \mathrm{min} \\
22 \mathrm{ng} / \mathrm{kg} / \mathrm{min} \\
-\end{array}$ \\
\hline Wray (1995) [24] & $1 / 0$ & 1 & 0 & 0 & & h & $\begin{array}{l}8-22 \mathrm{mcg} / \mathrm{min} \\
8 \mathrm{mcg} / \mathrm{min}\end{array}$ \\
\hline
\end{tabular}


Table 1 Blood pressure effect of angiotensin II from entire cohort (Continued)

\begin{tabular}{|c|c|c|c|c|c|c|c|}
\hline \multirow[t]{2}{*}{ Author (year) } & \multirow[t]{2}{*}{ Cases Total/+data } & \multicolumn{3}{|c|}{ Type of shock } & \multirow[t]{2}{*}{$\mathrm{SBP} \uparrow(\mathrm{mmHg})$} & \multirow[t]{2}{*}{$\mathrm{MAP} \uparrow(\mathrm{mmHg})$} & \multirow{2}{*}{$\begin{array}{l}\text { Dose range } \\
\text { Median } \\
\text { (IQR) }\end{array}$} \\
\hline & & Septic & Other & Cardiogenic & & & \\
\hline & & & & & & & - \\
\hline Tovar (1997) [23] & $1 / 1$ & 0 & 1 & 0 & 50.0 & & $\begin{array}{l}5-15 \mathrm{mcg} / \mathrm{min} \\
15 \mathrm{mcg} / \mathrm{min} \\
-\end{array}$ \\
\hline Eyraud (1998) [30] & $14 / 14$ & 0 & 14 & 0 & 74.0 & & $\begin{array}{l}2.5 \mathrm{mcg} \text { bolus } \\
- \\
-\end{array}$ \\
\hline Chawla (2014) [10] & $10 / 10$ & 10 & 0 & 0 & & 6.0 & $\begin{array}{l}15-20 \mathrm{ng} / \mathrm{kg} / \mathrm{min} \\
20 \mathrm{ng} / \mathrm{kg} / \mathrm{min} \\
-\end{array}$ \\
\hline Khanna (2017) [11] & $163 / 163$ & 163 & 0 & 0 & & 12.5 & $\begin{array}{l}20-40 \mathrm{ng} / \mathrm{kg} / \mathrm{min} \\
2.8 \mathrm{mg} \\
(5.8)\end{array}$ \\
\hline Total & $353 / 276$ & 225 & 90 & 38 & $71.3^{i}$ & $14.8^{\mathrm{i}}$ & \\
\hline
\end{tabular}

SBP systolic blood pressure, MAP mean arterial pressure, IQR interquartile range (in units similar to that study's dose range)

${ }^{a}$ From $52.8 \mathrm{mmHg}$ to $>100 \mathrm{mmHg}$ in 13 of 18 patients

${ }^{\mathrm{b}}$ Data unavailable

'From $<90 \mathrm{mmHg}$ to $>90 \mathrm{mmHg}$

${ }^{d}$ From BP of $76 / 48 \mathrm{mmHg}$ to DBP of $>68 \mathrm{mmHg}$

e $20 \mathrm{mmHg}$ increase from average SBP of $81.7 \mathrm{mmHg}$

fFrom $52 \mathrm{mmHg}$ to $>100 \mathrm{mmHg}$

${ }^{\mathrm{g}}$ From $50 \mathrm{mmHg}$ to $>100 \mathrm{mmHg}$

${ }^{h_{F}}$ From $<80 \mathrm{mmHg}$ to $>80 \mathrm{mmHg}$

'Weighted average

\section{Effects on organ perfusion}

Only seven of the 24 studies commented on lactate or UOP. Chawla et al. noted no change in lactate or UOP in the Ang II group [10], while Khanna et al. made no reference to either serum lactate or UOP [11]. None of the case controls or case studies reported serum lactate values, but five studies did comment on UOP [20-24]. Both Thomas et al. and Wray et al. describe anuria which persisted after the initiation of Ang II, while Jackson et al., Newby et al. and Tovar et al. report an improvement in UOP. Scarcity of data prevented any meaningful conclusion of the effect of Ang II on organ perfusion.

\section{Special considerations and sensitivity analysis}

Significant heterogeneity in study design and lack of a comparator in most studies prevented a thorough metaanalysis, though in 21 of 24 studies, we were able to extract patient-specific data. Additionally, the quality of the data presented within the various studies varied widely. (Additional file 1: Table S1) Two studies [10, 11] were graded as "A," nine studies [25-33] were graded as "B," and 13 studies [20-24, 34-41] were graded as "C." In the two RCTs $(n=173)$, an increase in MAP of $12.1 \mathrm{mmHg}$ was observed, with a concomitant decrease in norepinephrine doses $[10,11]$. In nine studies graded "B" $(n=75)$, SBP and MAP increased by $58.7 \mathrm{mmHg}$ and $25.1 \mathrm{mmHg}$, respectively. In 13 studies graded as
"C" $(n=28)$, SBP and MAP rose by $86.6 \mathrm{mmHg}$ and $25.8 \mathrm{mmHg}$.

Four studies included 18 patients described as having a SBP or MAP of $0 \mathrm{mmHg}$. While the studies did not overtly label these patients as having a cardiac arrest, we classified them as such. Among this cohort, complete data were available for 13 patients, and Ang II administration was associated with an increase in SBP of $107.3 \mathrm{mmHg}$, with a range of 0 to $250 \mathrm{mmHg}$ (Additional file 2: Table S2). Two of these 13 patients did not have return of spontaneous circulation (ROSC); and among the other five patients with incomplete data, two were nonresponders. When excluding all 18 cardiac arrest patients from the primary analysis, Ang II was found to increase SBP and MAP in all patients with circulatory shock by $58.0 \mathrm{mmHg}$ and $14.8 \mathrm{mmHg}$, respectively (Additional file 3: Table S3).

Of 276 patients for whom complete data existed, the recently published ATHOS-3 RCT accounted for 163 patients (59.3\% of the total cohort), and comprised $82.3 \%$ of the 198 patients with septic or distributive shock and complete data. Following exclusion of the ATHOS-3 cohort, we calculated BP change for the remaining cohort with complete data $(n=113)$, as well for the septic patients $(n=35)$, (Additional file 4: Table S4 and Additional file 5: Table S5). SBP and MAP rose by $70.0 \mathrm{mmHg}(n=58)$ and $21.7 \mathrm{mmHg}$ $(n=55)$, respectively, in the total cohort. In septic patients, 
Table 2 Blood pressure effect of Ang II versus other vasoactive medications

\begin{tabular}{|c|c|c|c|c|}
\hline Author (year) & $\begin{array}{l}\text { Total } \\
\text { number } \\
\text { of cases }\end{array}$ & $\begin{array}{l}\text { BP effects directly } \\
\text { associated with } \\
\text { Ang } \|\end{array}$ & $\begin{array}{l}\text { Cases with combined } \\
\text { effect (Ang II + other) }\end{array}$ & Disclosed effects in cases with combined medication (Ang $\|+$ other) \\
\hline Del Greco (1961) [25] & 20 & 17 & 3 & $\begin{array}{l}\text { All three patients with initial BP } 0 / 0 \text { (cardiac arrest). } 2 / 3 \text { had no ROSC } \\
\text { with addition of NE } 54-200 \mathrm{mcg} / \mathrm{min} \text {. } 1 / 3 \text { had ROSC with addition of } \\
\text { NE at unknown dose, resulting in BP 100/0. }\end{array}$ \\
\hline Nassif (1963) [34] & 14 & 14 & 0 & - \\
\hline Wedeen $^{\mathrm{a}}(1963)[35]$ & 15 & 7 & 0 & $\begin{array}{l}\text { Data available for only the } 7 \text { who responded. In these } 7 \text {, NE was } \\
\text { discontinued before Ang II started. }\end{array}$ \\
\hline Beanlands (1964) [36] & 17 & 13 & 4 & All 4 patients received concomitant EPI 2-4 mcg/min. \\
\hline Udhoji ${ }^{a}(1964)[26]$ & 12 & 6 & 0 & Data only available for 6 patients in whom Ang II was used alone. \\
\hline Belle (1965) [37] & 1 & 1 & 0 & $\begin{array}{l}\text { Co-administered with metaraminol (unknown dose) with hypotension } \\
\text { on metaraminol alone. BP rose as direct result of Ang II }\end{array}$ \\
\hline Cohn (1965) [27] & 6 & 6 & 0 & $\begin{array}{l}3 \text { of } 6 \text { patients received NE before Ang } \| \text { dose but NE was turned off } \\
\text { prior to Ang } \| \text { administration. }\end{array}$ \\
\hline Cohn (1965) [27] & 22 & 22 & 0 & - \\
\hline Singh (1966) [28] & 25 & 25 & 0 & - \\
\hline Wallace (1967) [29] & 7 & 7 & 0 & - \\
\hline Sorensen (1986) [32] & 8 & 8 & 0 & - \\
\hline Moore (1989) [33] & 9 & 9 & 0 & - \\
\hline Geary (1990) [38] & 1 & 1 & 0 & - \\
\hline Thacker (1990) & 2 & 0 & 2 & $\begin{array}{l}1 \text { patient received PHENYL (unknown dose), NE } 3 \mathrm{mcg} / \mathrm{kg} / \mathrm{min} \text {, an EPI } \\
\text { bolus (unknown dose) and DOPA } 5 \mathrm{mcg} / \mathrm{kg} / \mathrm{min} \text { plus Ang II. } 1 \text { patient } \\
\text { received DOPA } 5 \mathrm{mcg} / \mathrm{kg} / \mathrm{min} \text {, EPI } 4 \mathrm{mcg} / \mathrm{min} \text {, PHENYL (unknown } \\
\text { dose), and NE } 3 \mathrm{mcg} / \mathrm{kg} / \mathrm{min} \text { plus Ang II. }\end{array}$ \\
\hline Thomas (1991) [40] & 1 & 1 & 0 & $\begin{array}{l}\text { Co-administered with DOPA } 6 \text { mcg/kg/min, dobutamine (unknown } \\
\text { dose), and NE } 17 \mathrm{mcg} / \mathrm{kg} / \mathrm{min} \text {, but BP effect seen only after Ang II } \\
\text { administration. }\end{array}$ \\
\hline Jackson (1993) [20] & 1 & 1 & 0 & $\begin{array}{l}\text { Co-administered with DOPA } 3 \mathrm{mcg} / \mathrm{kg} / \mathrm{min} \text { and EPI } 0.02 \mathrm{mcg} / \mathrm{kg} / \mathrm{min} \text {, } \\
\text { but BP only responded after administration of Ang II. }\end{array}$ \\
\hline Trilli (1994) [21] & 1 & 1 & 0 & $\begin{array}{l}\text { Co-administered with DOPA } 20 \mathrm{mcg} / \mathrm{kg} / \mathrm{min} \text {, dobutamine (unknown } \\
\text { dose), and } \mathrm{NE} 14.5 \mathrm{mcg} / \mathrm{min} \text {, but upon initiation of Ang II NE dose } \\
\text { declined to } 7 \mathrm{mcg} / \mathrm{min} \text {. }\end{array}$ \\
\hline Ryding (1995) [41] & 1 & 1 & 0 & $\begin{array}{l}\text { Co-administered with DOPA } 4 \mathrm{mcg} / \mathrm{kg} / \mathrm{min} \text {, dobutamine (unknown } \\
\text { dose), and NE at } 28 \mathrm{mcg} / \mathrm{min} \text {, which were all titrated off after } \\
\text { administration of Ang II and amrinone (unknown dose). }\end{array}$ \\
\hline Newby (1995) [22] & 1 & 1 & 0 & $\begin{array}{l}\text { Co-administered with DOPA } 2.5 \mathrm{mcg} / \mathrm{kg} / \mathrm{min} \text { and NE } 1 \mathrm{mg} \text { bolus, but } \\
\text { BP only responded after Ang II administration. }\end{array}$ \\
\hline Wray (1995) [24] & 1 & 1 & 0 & $\begin{array}{l}\text { Co-administered with NE } 8.3 \mathrm{mcg} / \mathrm{kg} / \mathrm{min} \text { and DOPA (low unknown } \\
\text { dose), but BP only responded after administration of Ang II. }\end{array}$ \\
\hline Tovar (1997) [23] & 1 & 1 & 0 & $\begin{array}{l}\text { Co-administered with DOPA } 4.9 \mathrm{mcg} / \mathrm{kg} / \mathrm{min} \text { and NE } 60 \mathrm{mcg} / \mathrm{min} \text {. BP } \\
\text { only responded to addition of Ang II, which caused DOPA and NE to } \\
\text { be turned off, both of which had to be restarted with Ang II } \\
\text { cessation. }\end{array}$ \\
\hline Eyraud (1998) [30] & 14 & 14 & 0 & - \\
\hline Chawla (2014) [10] & 10 & 10 & 0 & $\begin{array}{l}\text { Co-administered with VASO } 0.02-0.08 \mathrm{u} / \mathrm{min} \text { and NE } 7.3-7.4 \mathrm{mcg} / \mathrm{min} \text {. } \\
\text { NE dose fell from a baseline } 19.8 \mathrm{mcg} / \mathrm{min} \text { upon initiation of Ang II. }\end{array}$ \\
\hline Khanna $^{\mathrm{b}}$ (2017) [11] & 163 & 163 & 0 & $\begin{array}{l}\text { Co-administered with a NE equivalent of } 0.45 \mathrm{mcg} / \mathrm{kg} / \mathrm{min} \text { ranging } \\
\text { down to } 0.4 \mathrm{mcg} / \mathrm{kg} / \mathrm{min} \text { during } 3 \text { hours of Ang II administration, } \\
\text { with positive BP effect seen at } 3 \text { hours, per study protocol. }\end{array}$ \\
\hline Total & 353 & 330 & 9 & \\
\hline
\end{tabular}

Ang II angiotensin II, BP blood pressure, ROSC return of spontaneous circulation, NE norepinephrine, EPI epinephrine, PHENYL phenylephrine, DOPA dopamine, VASO vasopressin

a Patients from Wedeen et al. and 6 patents from Udhoji et al. were included in total number of patients who received Ang II for hypotension, but were not included in any quantitative analysis due to incomplete data. It cannot be determined whether these patients received Ang II alone

${ }^{\mathrm{b}} \mathrm{NE}$ equivalence established a priori as part of ATHOS-3 protocol 
Table 3 Cardiogenic shock

\begin{tabular}{|c|c|c|c|c|}
\hline Author (year) & Cases & $\mathrm{SBP} \uparrow(\mathrm{mmHg})$ & $\mathrm{MAP} \uparrow(\mathrm{mmHg})$ & Dose range \\
\hline Del Greco (1961) [25] & 2 & 48.0 & & $1.2-1.8 \mathrm{mcg} / \mathrm{min}$ \\
\hline Nassif (1963) [34] & 2 & 87.5 & & $\begin{array}{l}7-350 \mathrm{mcg} \text { bolus, } \\
10.4-18.0 \mathrm{mcg} / \mathrm{min}\end{array}$ \\
\hline Wedeen (1963) [35] & 11 & $57.0^{\mathrm{a}}$ & & $1.5-36.0 \mathrm{mcg} / \mathrm{min}$ \\
\hline Beenlands (1964) [36] & 17 & b & & $1-36 \mathrm{mcg} / \mathrm{min}$ \\
\hline Udhoji (1964) [26] & 3 & & $45.0^{c}$ & N/A \\
\hline Belle (1965) [37] & 1 & 16.0 & & 50-250 mg/day \\
\hline Geary (1990) [38] & 1 & & 30.0 & $6 \mathrm{mcg} / \mathrm{min}$ \\
\hline Trilli (1994) [21] & 1 & 24.0 & & $8.5-9.0 \mathrm{mcg} / \mathrm{min}$ \\
\hline Total & 38 & $53.9^{\mathrm{d}}$ & $40.0^{d}$ & \\
\hline
\end{tabular}

SBP systolic blood pressure, MAP mean arterial pressure

${ }^{a}$ Data from four responders. Seven nonresponders not included due to incomplete data

${ }^{\mathrm{b}}$ From $52.8 \mathrm{mmHg}$ to $>100 \mathrm{mmHg}$ in 13 of 18 patients

${ }^{c}$ Data from two patients with complete data. A third patient had incomplete data

${ }^{\mathrm{d}}$ Weighted average

SBP and MAP rose by $53.9 \mathrm{mmHg}(n=14)$ and $19.9 \mathrm{mmHg}$ $(n=21)$

Seventy-one of the total of 353 (20.1\%) patients failed to respond adequately to Ang II, defined as either no response in BP or an increase in BP to a level below a MAP of $65 \mathrm{mmHg}$ or SBP $90 \mathrm{mmHg}$. Of 71 nonresponders, four had cardiac arrest. Fifty-two nonresponders had septic shock, including 48 identified in the ATHOS-3 study. Thirteen patients with cardiogenic shock failed to respond to Ang II, as did six with shock of other etiologies.

\section{Discussion}

Administration of Ang II in patients with hypotension appears to be associated with an increase in BP. The effect was seen in patients with shock of different etiologies, including distributive, cardiogenic, and other subtypes. Doses ranged from $15 \mathrm{ng} / \mathrm{kg} / \mathrm{min}$ to bolus therapy of $1500 \mathrm{mcg}$. Ang II also appears to be associated with an increase in BP in patients with angiotensinconverting enzyme (ACE) inhibitor overdose and in patients on chronic dialysis. The pressor effect of Ang II was variable, ranging from a decrease in MAP of $8 \mathrm{mmHg}$ to an increase in SBP of $250 \mathrm{mmHg}$ in all patients. Nonetheless, the weighted means remained fairly consistent among the total cohort and subgroups (Table 6). Sensitivity analyses following exclusion of ATHOS-3 and cardiac arrest patients yielded results similar to the primary analyses. Sensitivity analyses

Table 4 Septic shock

\begin{tabular}{lllll}
\hline Author (year) & Number of cases & SBP $\uparrow(\mathrm{mmHg})$ & MAP $\uparrow(\mathrm{mmHg})$ & Dose range \\
\hline Del Greco (1961) [25] & 7 & 29.3 & & $0.2-50.0 \mathrm{mcg} / \mathrm{min}$ \\
Nassif (1963) [34] & 6 & 73.3 & & $10-120 \mathrm{mcg}$ bolus, \\
& & & $2-15 \mathrm{mcg} / \mathrm{min}$ \\
Wedeen (1963) [35] & 1 & 110.0 & 40.5 & $11-21 \mathrm{mcg} / \mathrm{min}$ \\
Udhoji (1964) [26] & 4 & 29.7 & $\mathrm{a}$ \\
Cohn (1965) [27] & 6 & & $\mathrm{a}$ \\
Singh (1966) [28] & 25 & $\mathrm{c}$ & $4-12 \mathrm{mcg} / \mathrm{min}$ \\
Thomas (1991) [40] & 1 & 18.0 & $5-20 \mathrm{mcg} / \mathrm{min}$ \\
Ryding (1995) [41] & 1 & $\mathrm{~d}$ & $3.5-4.2 \mathrm{mcg} / \mathrm{min}$ \\
Wray (1995) [24] & 1 & & $8-22 \mathrm{mcg} / \mathrm{min}$ \\
Chawla (2014) [10] & 10 & & 12.5 & $15-20 \mathrm{ng} / \mathrm{kg} / \mathrm{min}$ \\
Khanna (2017) [11] & 163 & & $13.3^{\mathrm{e}}$ & $20-40 \mathrm{ng} / \mathrm{kg} / \mathrm{min}$ \\
Total & 225 & $53.9^{e}$ & & \\
\hline
\end{tabular}

SBP systolic blood pressure, MAP mean arterial pressure

${ }^{\text {a }}$ Data unavailable

${ }^{\text {b From }}<90 \mathrm{mmHg}$ to $>90 \mathrm{mmHg}$

'From $52 \mathrm{mmHg}$ to $>100 \mathrm{mmHg}$

${ }^{\mathrm{d}}$ From $<80 \mathrm{mmHg}$ to $>80 \mathrm{mmHg}$

'Weighted averages 
Table 5 Shock from other etiologies

\begin{tabular}{|c|c|c|c|c|}
\hline Author (year) & Number of cases & $\mathrm{SBP} \uparrow(\mathrm{mmHg})$ & $\operatorname{MAP} \uparrow(\mathrm{mmHg})$ & Dose range \\
\hline Del Greco (1961) [25] & 11 & 61.8 & & $0.8-130.0 \mathrm{mcg} / \mathrm{min}$ \\
\hline Nassif (1963) [34] & 6 & 129.2 & & $\begin{array}{l}25-1500 \mathrm{mcg} \text { bolus, } \\
8.6-68.0 \mathrm{mcg} / \mathrm{min}\end{array}$ \\
\hline Wedeen (1963) [35] & a & 115.0 & & $2-18 \mathrm{mcg} / \mathrm{min}$ \\
\hline Udhoji (1964) [26] & b & & 17.5 & c \\
\hline Cohn (1965) [27] & 22 & & 22.1 & $0.3-60.0 \mathrm{mcg} / \mathrm{min}$ \\
\hline Wallace (1967) [29] & 7 & & 22.9 & $0.75-3 \mathrm{mcg} / \mathrm{min}$ \\
\hline Sorensen (1986) [32] & 8 & e & & c \\
\hline Moore (1989) [33] & 9 & $f$ & & $30 \mathrm{ng} / \mathrm{kg} / \mathrm{min}$ \\
\hline Thacker (1990) & 2 & & 27.5 & $6-7 \mathrm{mcg} / \mathrm{min}$ \\
\hline Jackson (1993) [20] & 1 & d & & $3-18 \mathrm{mcg} / \mathrm{min}$ \\
\hline Newby (1995) [22] & 1 & 30.0 & & $0.8-2.2 \mathrm{mcg} / \mathrm{min}$ \\
\hline Tovar (1997) [23] & 1 & 50.0 & & $5-15 \mathrm{mcg} / \mathrm{min}$ \\
\hline Eyraud (1998) [30] & 14 & 74.0 & & $2.5 \mathrm{mcg}$ bolus \\
\hline Total & 90 & $80.0^{9}$ & $12.0^{9}$ & \\
\hline
\end{tabular}

SBP systolic blood pressure, MAP mean arterial pressure

${ }^{a}$ Two patients with complete data. One with no data was a nonresponder

Includes only two patients with data

'Data unavailable

${ }^{\mathrm{d}}$ From $50 \mathrm{mmHg}$ to $>100 \mathrm{mmHg}$

${ }^{e}$ From BP of $76 / 48$ to DBP of $>68$

${ }^{f} 20 \mathrm{mmHg}$ increase from average SBP of $81.7 \mathrm{mmHg}$

${ }^{g}$ Weighted averages

according to the quality of studies were not substantially different, but did reflect a trend toward more robust results in poorer quality studies.

The two included RCTs demonstrated an improvement of BP by only $6.0 \mathrm{mmHg}(8.7 \%)$ and $12.5 \mathrm{mmHg}$ $(18.9 \%)[10,11]$. However, this was achieved in the context of a concomitant decrease in catecholamine doses [10] or as part of a protocolized BP endpoint which included titration of Ang II to a target MAP increase of
$10 \mathrm{mmHg}$ [11]. As such, comparisons to other studies is challenging. Nonetheless, the catecholamine-sparing effect and BP effect in these studies are consistent with the conclusion contained herein.

The consistent BP increase from Ang II may be explained in teleological terms. Ang II is a molecule innate to human physiology and, along with catecholamines and vasopressin, helps maintain BP throughout a variety of conditions. Its widely described effects include direct

Table 6 Summary of results

\begin{tabular}{lllll}
\hline Cohort & From & $\begin{array}{l}\text { Cases with complete } \\
\text { data }\end{array}$ & $\begin{array}{l}\text { Increase in SBP } \\
\text { (mmHg) }\end{array}$ & $\begin{array}{l}\text { Increase in MAP } \\
\text { (mmHg) }\end{array}$ \\
\hline All patients & Table 1 & 276 & 71.3 & 14.8 \\
Cardiogenic & Table 2 & 38 & 53.9 & 40.0 \\
Septic & Table 3 & 225 & 52.3 & 13.3 \\
Other & Table 4 & 90 & 80.0 & 12.0 \\
Cardiac arrest patients & Table 5 & 18 & 107.3 & 12.1 \\
"A" studies & Additional file 1: Table S1 & 173 & 58.4 & 25.1 \\
"B" studies & Additional file 1: Table S1 & 75 & 86.6 & 25.8 \\
"C" studies & Additional file 1: Table S1 & 28 & 58.0 & 14.8 \\
All patients except cardiac arrest & Additional file 2: Table S2 & 264 & 70.0 & 21.7 \\
All patients except ATHOS-3 & Additional file 3: Table S3 & 113 & 52.3 & 17.7 \\
All septic patients except ATHOS-3 & Additional file 4: S4 & 63 & & 8.7 \\
Standard error & & & & \\
\hline
\end{tabular}


vasoconstriction of peripheral vessels, potentiation of water reabsorption as part of the renin-angiotensinaldosterone system (RAAS), and interaction with other endogenous pressors (catecholamines and vasopressin). It is produced via multiple pathways throughout various tissue types and has important autocrine and paracrine functions, including participation in the cellular lifecycle and immune regulation [42]. The ubiquity of Ang II, its precursors and derivatives, and its receptors underlie a complex, highly evolved, homeostatic system of BP regulation. For example, RAAS activation during longstanding cardiovascular disease increases BP to maintain perfusion, but it also potentiates cardiac remodeling to withstand this increased BP [43]. Ang II also helps regulate and maintain glomerular filtration, especially during periods of reduced renal perfusion $[44,45]$.

Since its discovery in the 1930s, Ang II has been reported in over 31,000 humans in 1124 studies [19]. In the mid-1960s, intravenous Ang II was administered to pregnant women for preeclampsia evaluation $[15,16]$. It has also been used in patients with a multitude of diseases, including circulatory shock $[17,24,40,41,46]$ and ACE inhibitor overdose [20-22]. The 2014 ATHOS RCT highlighted the catecholamine-sparing effect of Ang II in patients with distributive shock [10]. Results of the recently completed ATHOS-3 study have confirmed its beneficial effect and safety in patients with distributive shock refractory to conventional vasopressor therapy [11].

Importantly, Ang II has been implicated as contributing to cardiac pathophysiology. Activation of the RAAS is associated with ventricular remodeling both at the site of infarct and remotely after myocardial ischemia [47]. Ang II also increases sympathoexcitation, which leads to hypertension and other cardiovascular diseases [48], and it upregulates peptides causing fibrogenesis, chemotaxis of fibroblasts, and scar formation in the healing heart [49]. ACE concentrations within myocardial tissue correlate with tissue collagen levels, and processes like fibrogenesis may cause further ACE accumulation in areas of cardiac remodeling [47]. Due to its ability to mitigate adverse myocardial remodeling, ACE inhibition has become the standard of care for patients with congestive heart failure [50]. Despite inhibition, however, patients with congestive heart failure can have elevated Ang II levels, which are associated with worse morbidity and mortality [51, 52]. Long-term effects of intravenous Ang II on cardiovascular health are unknown.

The cardiogenic shock population deserves special mention because of its exclusion from the two aforementioned RCTs $[10,11]$. Scant data describe ACE or Ang II levels in patients with cardiogenic shock, though increased levels of Ang II and downregulation of Ang II receptors have been reported in other forms of shock $[42,53,54]$. Patients with cardiogenic shock may have a relative deficiency of Ang II, based on similar pathogenic mechanisms. While many studies in this review predate the widespread use of ACE inhibitors, the effect of Ang II in the five patients evaluated in the ACE-inhibition era [i.e., occurring after practice changes as a result of Cooperative North Scandinavian Enalapril Survival Study (CONSENSUS) and Studies of Left Ventricular Dysfunction (SOLVD) trials] suggest a potential role in patients on ACE inhibition who present with cardiogenic shock $[55,56]$. Notably, four of the five patients had premorbid ACE inhibitor use, while information was unavailable for the remaining patient. The profound effect seen in these five patients $(83.9 \%$ increase from baseline BP) suggests that administration of exogenous Ang II may restore the RAAS effect on BP. While exposure to angiotensin receptor blocker (ARB) therapy was noted in in the study by Khanna et al., the impact of ARB therapy was not specifically investigated [11]. In fact, the effect of Ang II on patients pre-treated with ARB therapy may be difficult to predict owing to heterogeneity in pharmacodynamics and pharmacokinetics of ARB therapy [56-58]

Eighteen patients included in this analysis had an initial BP of $0 \mathrm{mmHg}$, suggesting a condition of cardiac arrest. The pressor effect seen in these patients ranged from no change in BP (no ROSC) to an increase of $250 \mathrm{mmHg}$. The mean effect was $107.3 \mathrm{mmHg}$ in patients with ROSC. Although cardiac arrest in these patients cannot be verified, their successful resuscitation suggests a potential role of Ang II to achieve ROSC. Ang II has not been described specifically for cardiac arrest, but a 2016 porcine cardiac arrest study examined Ang II levels with and without ACE inhibitor pretreatment [59]. Angiotensin (1-7) and Ang II levels increased in all animals after ROSC, though the effect on Ang II was muted in the ACE inhibitor-treated group and survival did not differ between groups. It should be noted that Wang et al. hypothesize that ACE inhibition, rather than an increase in Ang II, is beneficial in a cardiac arrest situation due to amelioration of ischemia-reperfusion injury in the myocardium as shown in a pig model. Nonetheless, the manipulation of the RAAS system in cardiac arrest may be a potential target for future investigation, as ischemiareperfusion injury would be predicted to happen in all therapies for resuscitation, including catecholamines (which are the current standard of care). The mechanisms surrounding a potential benefit of Ang II in cardiac arrest are only speculative but may include: (a) maintenance of adequate systemic BP to vital organs [60], (b) manipulation of intracellular calcium levels leading to increased inotropy [61, 62], (c) potentiation of catecholamines [63, 64], and (d) increased afterload for enhancement of coronary perfusion [65]. Our observations are hypothesisgenerating and require further properly constructed RCTs to elucidate the role of Ang II in cardiac arrest. 
To our knowledge, this is the only analysis to thoroughly review the association of Ang II with increases in BP in patients with circulatory shock. The systematic selection of studies, the reproducibility of search results, and careful extraction of data support the comprehensiveness of the analysis. The consistent observed pressor effect over a wide variety of patients with different clinical conditions over a 66-year period (1961-2017) adds credence to the generalizability of the results.

This analysis has a number of weaknesses, including the lack of quality data. Only two of 24 studies analyzed were RCTs, with other studies being case-control and casestudy formats. As such, the lack of a comparator to Ang II limits our ability to conclude causality. Of the 353 patients included in the analysis, 163 were from one source, potentially leading to a skewed effect [11]. However, this one source was a well-designed RCT, lending credibility to the results. Additionally, the risk of publication bias exists, as we were unable to identify any papers reporting lack of effect in patients treated with Ang II. Most studies were designed to address research questions either unrelated or tangentially related to the pressor effect of Ang II. Nonetheless, included in this analysis are 51 patients in the two RCTs who received Ang II but did not respond, as well as 30 nonresponders in the case-control analyses and case studies. The inclusion of nonresponders, in our opinion, mitigates publication bias. The quality and heterogeneity of data (e.g., BP variably reported as MAP, SBP, or DBP, and some BP reported graphically or qualitatively as "normal") limit robust quantitative analysis. However, this heterogeneity was expected, and the a priori primary endpoint was designed specifically to account for this. We chose a simple, easy-to-identify, frequently reported endpoint (BP) so as to be able to include as many data points as possible. The specific effect of Ang II may also be questioned, as many studies described its BP effect in association with the co-administration of other vasoactive medications (e.g., norepinephrine, epinephrine, and amrinone). However, this approach mirrors clinical management of shock, in which multiple agents are often used. Moreover, Ang II was evaluated in the ATHOS-3 study as a therapeutic adjunct to other drugs, including catecholamines and vasopressin, which may add legitimacy to our results [11]. In both RCTs included herein, doses of catecholamines and vasopressin were controlled, allowing for clear elucidation of the isolated effect of Ang II. In further analysis, the observed BP effects in a vast majority of the patients analyzed herein can be attributed to or associated with Ang II alone, with only a handful of patients $(n=9)$ responding to a combination of medications including Ang II. Much of the analysis contained herein is derived from fairly old data. Ten of the 24 studies were published in the 1960s, while two were published in the 1980s, and ten in the 1990s. Only two studies (the two RCTs) have been published since the year 2000. As such, the standard of care for many disease states may be substantially different today. For example, ARB therapy is only described in the study by Khanna et al., despite the common use of this class of medication currently. ARB therapy may significantly affect the clinical response to Ang II, the effects of which remain unknown. Finally, as part of our comprehensive search, we deliberately omitted non-English language sources, and may have inadvertently omitted relevant English-language sources.

\section{Conclusions}

In conclusion, Ang II appears to be associated with an increase in BP in patients with circulatory shock. The effect was robust, with increases in excess of $70 \mathrm{mmHg}$ in SBP and $14 \mathrm{mmHg}$ in MAP from the entire patient cohort, and remained observable in shock of various etiologies, including distributive, cardiogenic, and other circulatory shock. Observations in patients with cardiogenic shock and with ACE inhibitor use suggests a potential role for Ang II in patients with ACE depletion, either from acute ACE inhibitor overdose or as part of chronic heart disease management. Moreover, a role for Ang II in patients with cardiac arrest may warrant further exploration. More research, including well-designed randomized, controlled analyses are required to answer these questions.

\section{Additional files}

Additional file 1: Table S1. Data analysis categorized by quality of study, describes primary analysis broken into subgroups based on a priori categorized study quality, which rates RCTs as "A," case controls as "B," and case reports as " $\mathrm{C}$ ". (DOCX $17 \mathrm{~kb})$

Additional file 2: Table S2. Cardiac arrest, describes results of the Ang Il effect associated with all patients identified by the authors as being in a state of cardiac arrest (i.e., BP of 0/0). (DOCX $13 \mathrm{~kb}$ )

Additional file 3: Table S3. Results after removal of all cardiac arrest patients, describes primary analysis after removal of all patients identified by the authors as being in a state of cardiac arrest (i.e., BP of 0/0). (DOCX $15 \mathrm{~kb}$ )

Additional file 4: Table S4. Results with patients from Khanna et al. Rrmoved, describes primary analysis after exclusion of the patients from Khanna et al., which represent a proportionally large amount of the total patients included in the analysis. (DOCX $17 \mathrm{~kb}$ )

Additional file 5: Table S5. Septic shock results removing patients from Khanna et al., describes the analysis of Ang II $n$ the septic shock sub-group after exclusion of the patients from Khanna et al., which represent a proportionally large amount of the total patients included in the analysis. (DOCX $13 \mathrm{~kb}$ )

\section{Abbreviations}

ACE: Angiotensin-converting enzyme; ACTH: Adrenocorticotropin hormone; ADH: Antidiuretic hormone; Ang II: Angiotensin II; ARB: Angiotensin receptor blocker; ATHOS: Angiotensin II for the Treatment of High Output Shock; BP: Blood pressure; CONSENSUS: Cooperative North Scandinavian Enalapril Survival Study; DBP: Diastolic blood pressure; MAP: Mean arterial pressure; RAAS: Renin-angiotensin-aldosterone system; RCT: Randomized, controlled trial; ROSC: Return of spontaneous circulation; SBP: Systolic blood pressure; SE: Standard error; SOLVD: Studies of Left Ventricular Dysfunction; UOP: Urine output 


\section{Acknowledgements}

Not applicable.

\section{Funding}

The authors report no external funding associated with the preparation of this manuscript.

\section{Availability of data and materials}

All data included herein has been extracted from original published sources which are available through the PubMed (www.ncbi.nlm.hih.gov), EMBASE (www.embase.com), Medline (www.ncbi.nlm.nih.gov/pubmed/

(www.ncbi.nlm.nih.gov/pubmed/)) and OVID (www.ovid.com) databases.

\section{Authors' contributions}

All authors (LWB, MM, MO, OA, $\mathrm{AH}$, and $\mathrm{HC}$ ) assisted in collecting and analyzing data as well as preparation of the manuscript. All authors have read and approved the final manuscript.

\section{Ethics approval}

Not applicable.

\section{Consent for publication}

Not applicable.

\section{Competing interests}

The authors declare that they have no competing interests.

\section{Publisher's Note}

Springer Nature remains neutral with regard to jurisdictional claims in published maps and institutional affiliations.

\section{Author details}

'Department of Medicine, Division of Pulmonary, Critical Care, Allergy, and Sleep Medicine, Emory University, Emory St. Joseph's Hospital, 5665 Peachtree Dunwoody Road, Atlanta, GA 30342, USA. ²Division of Pulmonary \& Critical Care, Department of Medicine, University of Maryland School of Medicine, Baltimore, MD, USA. ${ }^{3}$ Department of Emergency Medicine, University of Maryland School of Medicine, Baltimore, MD, USA. ${ }^{4}$ Department of Critical Care, King's College London, Guy's \& St Thomas' NHS Foundation Hospital, London SE1 7EH, UK.

\section{Received: 28 July 2017 Accepted: 28 November 2017}

\section{Published online: 28 December 2017}

\section{References}

1. Gamper G, Havel C, Arrich J, Losert H, Pace NL, Mullner M, Herkner H. Vasopressors for hypotensive shock. Cochrane Database Syst Rev. 2016;2, CD003709.

2. De Backer D, Biston P, Devriendt J, Madl C, Chochrad D, Aldecoa C, Brasseur A, Defrance $P$, Gottignies P, Vincent JL. Comparison of dopamine and norepinephrine in the treatment of shock. N Engl J Med. 2010;362(9):779-89.

3. Hiltebrand LB, Krejci V, Jakob SM, Takala J, Sigurdsson GH. Effects of vasopressin on microcirculatory blood flow in the gastrointestinal tract in anesthetized pigs in septic shock. Anesthesiology. 2007:106(6):1156-67.

4. Schmittinger CA, Torgersen C, Luckner G, Schroder DC, Lorenz I, Dunser MW. Adverse cardiac events during catecholamine vasopressor therapy: a prospective observational study. Intensive Care Med. 2012;38(6):950-8

5. Dunser MW, Mayr AJ, Ulmer $\mathrm{H}$, Knotzer $\mathrm{H}$, Sumann G, Pajk W, Friesenecker B, Hasibeder WR. Arginine vasopressin in advanced vasodilatory shock: a prospective, randomized, controlled study. Circulation. 2003;107(18):2313-9.

6. Sakr Y, Reinhart K, Vincent $J$, Sprung CL, Moreno R, Ranieri VM, De Backer D, Payen D. Does dopamine administration in shock influence outcome? Results of the Sepsis Occurrence in Acutely III Patients (SOAP) Study. Crit Care Med. 2006;34(3):589-97.

7. Myburgh JA, Higgins A, Jovanovska A, Lipman J, Ramakrishnan N, Santamaria J. A comparison of epinephrine and norepinephrine in critically ill patients. Intensive Care Med. 2008;34(12):2226-34

8. Russell JA, Walley KR, Singer J, Gordon AC, Hebert PC, Cooper DJ, Holmes CL, Mehta S, Granton JT, Storms MM, et al. Vasopressin versus norepinephrine infusion in patients with septic shock. N Engl J Med. 2008;358(9):877-87.
9. Zhou F, Mao Z, Zeng X, Kang H, Liu H, Pan L, Hou PC. Vasopressors in septic shock: a systematic review and network meta-analysis. Ther Clin Risk Manag. 2015;11:1047-59.

10. Chawla LS, Busse L, Brasha-Mitchell E, Davison D, Honiq J, Alotaibi Z, Seneff MG. Intravenous angiotensin II for the treatment of high-output shock (ATHOS trial): a pilot study. Crit Care. 2014;18(5):534.

11. Khanna A, English SW, Wang XS, Ham K, Tumlin J, Szerlip H, Busse LW Altaweel L, Albertson TE, Mackey C, et al. Angiotensin II for the treatment of vasodilatory shock. N Engl J Med. 2017;377(5):419-30.

12. Campbell DJ. Do intravenous and subcutaneous angiotensin II increase blood pressure by different mechanisms? Clin Exp Pharmacol Physiol. 2013; 40(8):560-70.

13. Ames RP, Borkowski AJ, Sicinski AM, Laragh JH. Prolonged infusions of angiotensin ii and norepinephrine and blood pressure, electrolyte balance, and aldosterone and cortisol secretion in normal man and in cirrhosis with ascites. J Clin Invest. 1965:44:1171-86

14. Oelkers W, Schoneshofer M, Schultze G, Brown JJ, Fraser R, Morton JJ, Lever AF, Robertson Jl. Effect of prolonged low-dose angiotensin II infusion on the sensitivity of adrenal cortex in man. Circ Res. 1975:36(6 Suppl 1):49-56.

15. Conti C, Tranquilli AL, Garzetti GG, Romanini C. Modulation of vascular reactivity after acute calcium antagonist administration in pregnant women moderately sensitive to angiotensin infusion. Boll Soc Ital Biol Sper. 1994;70(10-11):243-8.

16. Oney $\mathrm{T}$, Kaulhausen $\mathrm{H}$. The value of the angiotensin sensitivity test in the early diagnosis of hypertensive disorders in pregnancy. Am J Obstet Gynecol. 1982;142(1):17-20.

17. Yunge $M$, Petros $A$. Angiotensin for septic shock unresponsive to noradrenaline. Arch Dis Child. 2000;82(5):388-9.

18. Cumming GR. Acute hemodynamic effects of angiotensin II. Preliminary report. Can Med Assoc J. 1963;88:827-32.

19. Busse LW, Wang XS, Chalikonda DM, Finkel KW, Khanna AK, Szerlip HM, Yoo D, Dana SL, Chawla LS. Clinical eexperience with IV angiotensin II administration: a systematic review of safety. Crit Care Med. 2017:45(8):1285-94.

20. Jackson T, Corke C, Agar J. Enalapril overdose treated with angiotensin infusion. Lancet. 1993:341(8846):703.

21. Trilli LE, Johnson KA. Lisinopril overdose and management with intravenous angiotensin II. Ann Pharmacother. 1994;28(10):1165-8.

22. Newby DE, Lee MR, Gray AJ, Boon NA. Enalapril overdose and the corrective effect of intravenous angiotensin II. Br J Clin Pharmacol. 1995:40(1):103-4.

23. Tovar JL, Bujons I, Ruiz JC, Ibanez L, Salgado A. Treatment of severe combined overdose of calcium antagonists and converting enzyme inhibitors with angiotensin II. Nephron. 1997;77(2):239.

24. Wray GM, Coakley JH. Severe septic shock unresponsive to noradrenaline. Lancet. 1995:346(8990):1604.

25. Del Greco F, Johnson DC. Clinical experience with angiotensin II in the treatment of shock. JAMA. 1961:178:994-9.

26. Udhoji VN, Weil MH. Circulatory effects of angiotensin, levarterenol and metaraminol in the treatment of shock. N Engl J Med. 1964:270:501-5.

27. Cohn JN, Luria MH. Studies in clinical shock and hypotension. 3 . Comparative effects of vasopressor drugs and dextran. Arch Intern Med. 1965;116(4):562-6.

28. Singh S, Malhotra RP. Comparative study of angiotensin and nor-adrenaline in hypotensive states (shock). J Assoc Physicians India. 1966;14(11):639-45.

29. Wallace JM, Lopez G, Malo-Camacho R, DeLeon JA, Walker JP, Kirksey TD, Derrick JR. Hemodynamic effects of angiotensin during surgical anesthesia. Am Heart J. 1967:73(3):326-33.

30. Eyraud D, Mouren S, Teugels K, Bertrand M, Coriat P. Treating anesthesia-induced hypotension by angiotensin II in patients chronically treated with angiotensin-converting enzyme inhibitors. Anesth Analg. 1998;86(2):259-63.

31. Cohn JN, Luria MH. Studies in clinical shock and hypotension. ii. hemodynamic effects of norepinephrine and angiotensin. J Clin Invest. 1965:44:1494-504

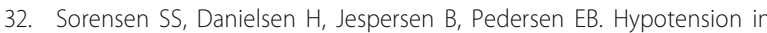
end-stage renal disease: effect of postural change, exercise and angiotensin II infusion on blood pressure and plasma concentrations of angiotensin II, aldosterone and arginine vasopressin in hypotensive patients with chronic renal failure treated by dialysis. Clin Nephrol. 1986:26(6):288-96.

33. Moore TJ, Lazarus JM, Hakim RM. Reduced angiotensin receptors and pressor responses in hypotensive hemodialysis patients. Kidney Int. 1989: 36(4):696-701. 
34. Nassif AC, Nolan TR, Corcoran AC. Angiotensin II in treatment of hypotensive states. JAMA. 1963;183:751-4.

35. Wedeen R, Zucker G. Angiotensin II in the treatment of shock. Am J Cardiol. 1963;11:82-6.

36. Beanlands DS, Gunton RW. Angiotensin ii in the treatment of shock following myocardial infarction. Am J Cardiol. 1964;14:370-3.

37. Belle MS, Jaffee RJ. The use of large doses of angiotensin in acute myocardial infarction with shock. J Lancet. 1965;85:193-4.

38. Geary VM, Thaker UN, Chalmers PC, Sheikh F. The use of angiotensin II to treat profound hypotension in a patient taking amiodarone. J Cardiothorac Anesth. 1990;4(3):364-7.

39. Thaker U, Geary V, Chalmers P, Sheikh F. Low systemic vascular resistance during cardiac surgery: case reports, brief review, and management with angiotensin II. J Cardiothorac Anesth. 1990;4(3):360-3.

40. Thomas VL, Nielsen MS. Administration of angiotensin II in refractory septic shock. Crit Care Med. 1991;19(8):1084-6.

41. Ryding J, Heslet L, Hartvig T, Jonsson V. Reversal of 'refractory septic shock' by infusion of amrinone and angiotensin II in an anthracycline-treated patient. Chest. 1995;107(1):201-3.

42. Antonucci E, Gleeson PJ, Annoni F, Agosta S, Orlando S, Taccone FS, Velissaris D, Scolletta S. Angiotensin II in refractory septic shock. Shock. 2017; 47(5):560-6.

43. Struthers AD, MacDonald TM. Review of aldosterone- and angiotensin II-induced target organ damage and prevention. Cardiovasc Res. 2004;61(4):663-70.

44. Hall JE, Coleman TG, Guyton AC, Kastner PR, Granger JP. Control of glomerular filtration rate by circulating angiotensin II. Am J Phys. 1981; 241(3):R190-7.

45. Kastner PR, Hall JE, Guyton AC. Control of glomerular filtration rate: role of intrarenally formed angiotensin II. Am J Phys. 1984;246(6 Pt 2):F897-906.

46. Whiteley SM, Dade JP. Treatment of hypotension in septic shock. Lancet 1996;347(9001):622.

47. Weber KT. Extracellular matrix remodeling in heart failure: a role for de novo angiotensin II generation. Circulation. 1997;96(11):4065-82.

48. Basu U, Seravalli J, Madayiputhiya N, Adamec J, Case AJ, Zimmerman MC. Rapid metabolism of exogenous angiotensin II by catecholaminergic neuronal cells in culture media. Physiol Rep. 2015;3(2).

49. Rosenkranz S. TGF-beta1 and angiotensin networking in cardiac remodeling Cardiovasc Res. 2004;63(3):423-32

50. Pouleur H, Rousseau MF, van Eyll C, Stoleru L, Hayashida W, Udelson JA, Dolan N, Kinan D, Gallagher P, Ahn S, et al. Effects of long-term enalapril therapy on left ventricular diastolic properties in patients with depressed ejection fraction. SOLVD Investigators. Circulation. 1993;88(2):481-91.

51. Roig E, Perez-Villa F, Morales M, Jimenez W, Orus J, Heras M, Sanz G. Clinical implications of increased plasma angiotensin II despite ACE inhibitor therapy in patients with congestive heart failure. Eur Heart J. 2000;21(1):53-7.

52. van de Wal RM, Plokker HW, Lok DJ, Boomsma F, van der Horst FA, van Veldhuisen DJ, van Gilst WH, Voors AA. Determinants of increased angiotensin II levels in severe chronic heart failure patients despite ACE inhibition. Int J Cardiol. 2006;106(3):367-72.

53. Bucher M, Ittner KP, Hobbhahn J, Taeger K, Kurtz A. Downregulation of angiotensin II type 1 receptors during sepsis. Hypertension. 2001;38(2): 177-82.

54. Salgado DR, Rocco JR, Silva E, Vincent JL. Modulation of the reninangiotensin-aldosterone system in sepsis: a new therapeutic approach? Expert Opin Ther Targets. 2010;14(1):11-20.

55. Yusuf S, Pitt B, Davis CE, Hood WB, Cohn JN. Effect of enalapril on survival in patients with reduced left ventricular ejection fractions and congestive heart failure. N Engl J Med. 1991;325(5):293-302.

56. Liu YJ, Shnkley NP, Welsh NJ, Black JW. Effects of enalapril on mortality in severe congestive heart failure. Results of the Cooperative North Scandinavian Enalapril Survival Study (CONSENSUS). N Engl J Med. 1987; 316(23):1429-35.

57. Ojima M, Inada Y, Shibouta Y, Wada T, Sanada T, Kubo K, Nishikawa K. Candesartan (CV-11974) dissociates slowly from the angiotensin AT1 receptor. Eur J Pharmacol. 1997;319(1):137-46.

58. McConnaughey MM, McConnaughey JS, Ingenito AJ. Practical considerations of the pharmacology of angiotensin receptor blockers. J Clin Pharmacol. 1999; 39(6):547-59.

59. Wang G, Zhang Q, Yuan W, Wu J, Li C. Enalapril protects against myocardial ischemia/reperfusion injury in a swine model of cardiac arrest and resuscitation. Int J Mol Med. 2016;38(5):1463-73.
60. Bjerregaard J, Jaffe RA. Intraoperative cardiac arrest: was it the ACE inhibitor? J Clin Anesth. 2014;26(1):62-4.

61. Dhingra R, Kirshenbaum LA. Negative inotropy by angiotensin II is mediated via phosphoinositide 3-kinase alpha-protein kinase C-coupled signaling pathway. Hypertension. 2010;56(3):349-50.

62. Liang W, Oudit GY, Patel MM, Shah AM, Woodgett JR, Tsushima RG, Ward ME, Backx PH. Role of phosphoinositide 3-kinase \{alpha\}, protein kinase C, and L-type Ca2+ channels in mediating the complex actions of angiotensin II on mouse cardiac contractility. Hypertension. 2010;56(3):422-9.

63. Clemson B, Gaul L, Gubin SS, Campsey DM, McConville J, Nussberger J, Zelis R. Prejunctional angiotensin II receptors. Facilitation of norepinephrine release in the human forearm. J Clin Invest. 1994;93(2):684-91.

64. Lyons D, Webster J, Benjamin N. Angiotensin II. Adrenergic sympathetic constrictor action in humans. Circulation. 1995;91(5):1457-60.

65. Paradis NA, Martin GB, Rivers EP, Goetting MG, Appleton TJ, Feingold M, Nowak RM. Coronary perfusion pressure and the return of spontaneous circulation in human cardiopulmonary resuscitation. JAMA. 1990;263(8):1106-13.

\section{Submit your next manuscript to BioMed Central and we will help you at every step:}

- We accept pre-submission inquiries

- Our selector tool helps you to find the most relevant journal

- We provide round the clock customer support

- Convenient online submission

- Thorough peer review

- Inclusion in PubMed and all major indexing services

- Maximum visibility for your research

Submit your manuscript at www.biomedcentral.com/submit
) Biomed Central 